\title{
Diversification of Russian energy exports to Asia-Pacific countries: opportunities and risks
}

\author{
V. V. Avilova ${ }^{1, *}, A . V$. Safina $^{1}$, and E. V. Demidova ${ }^{1}$ \\ ${ }^{1}$ Kazan National Research Technological University, Kazan, Russia
}

\begin{abstract}
We have analyzed the dynamics of Russian energy exports with an outlook up to 2040. This paper justifies the need to diversify Russian energy supplies to the Asia-Pacific countries and defines the areas of mutually beneficial relations. It also considers the positive effects of mutual cooperation projects, possible risks, and the conditions for their mitigation.
\end{abstract}

\section{Introduction}

In recent decades, the global fuel and energy market has been undergoing profound transformations which have significantly changed the volume and structure of the demand and led to increased competition in all key Russian energy export markets. Countries seek to diversify national energy supply systems, which is shown in an effort to reduce dependence on energy imports by increasing their own production of hydrocarbons (including development of new difficult oil production technologies), development of renewable energy sources, use of nonconventional fuels. This, in turn, leads to a narrowing of market niches for Russia.

Besides, there are significant transformations in hydrocarbon supply, which is due to development of new oil production technologies and the high oil prices for the previous ten years. Thus, production projects were started in countries where hydrocarbons were not previously produced - for example, in Israel (gas, 2013), Ghana (oil, 2010), South Korea (gas, 2004) [1].

The increasing demand for fuel and other types of energy on the one hand and the depletion of natural energy resources on the other hand make the problem of maintaining energy security and development and implementation of national strategies in this area for different countries increasingly urgent [2].

There was an increase in production of unconventional hydrocarbons in North America, primarily due to a breakthrough in unconventional oil and gas production, which in the coming years can lead to freedom from their imports and the USA becoming an LNG net exporter. In Japan, successful experiments on deep-sea gas hydrates development were conducted, which allowed us to talk about the beginning of a new era in the use of hydrocarbons [1].

Energy supplies diversification is currently one of the key problems in implementation of national energy strategies for all players in the global energy market: exporters, importers, and transit countries. At the same time, their interest alignment has become a priority area of the global policy.

In this regard, the following tasks were set:

- to substantiate the need to diversify Russia's energy supplies to the Asia-Pacific countries;

- to determine the main areas of mutually beneficial relations between Russia and the Asia-Pacific countries;

- to reflect the positive effects of mutual cooperation projects, consider the possible risks and the proposals on their mitigation.

\section{Analysis of Russian energy exports}

The issues of ensuring uninterrupted supply of energy and diversification of energy sources are very relevant for the EU. The need for geographical diversification was keenly felt during the oil crises, so the main efforts of the EU are aimed at reducing the dependence on external sources of supply, primarily of oil and gas, and the transition to clean energy based on renewable sources $[3,4]$.

In the future, this situation cannot but affect the position of Russia as one of the world's leading exporters of hydrocarbons. Therefore, in the long term (by the end of 2040), the total exports of our country is expected to reduce [5], which is primarily due to reduction in the volume of exported oil and petroleum products (Figure 1).

The changed state of the world energy markets does not allow Russia to increase the volume of energy exports as it did in the first decade of the 21 st century. According to experts, this index will either stabilize (or even decrease), or - in the most favorable case - will increase by $10 \%$ by 2040 [5].

In Russia, in the last 10-15 years, the export energy infrastructure has been developed to solve mainly two key problems: ensuring direct energy supplies to the West and South (including in order to bypass the transit of Eastern European countries) and development of new energy transport routes to East Asia. In both areas,

\footnotetext{
* Corresponding author: alb_saf@mail.ru
} 


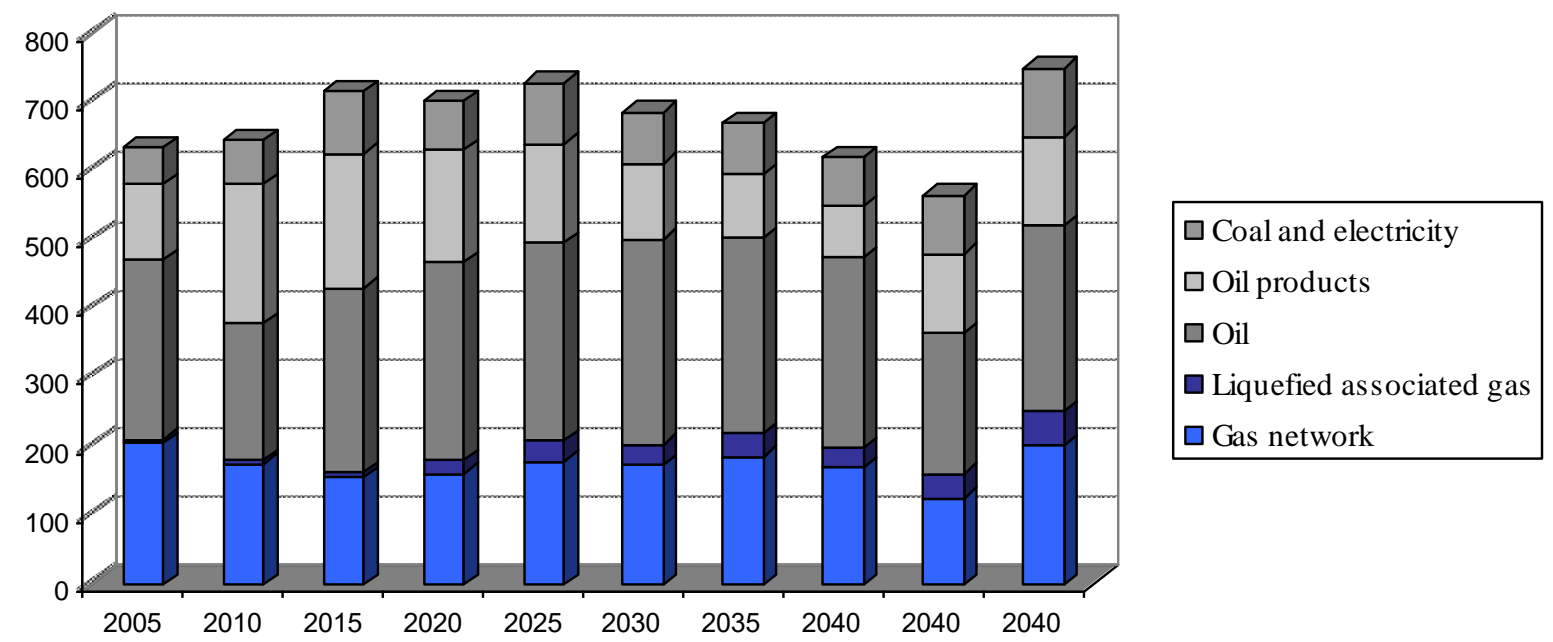

Fig. 1. Russian exports by types of energy resources (actual and forecast) [5].

significant results have been achieved through development of pipeline and port infrastructure, and this process continues. However, while in the West no significant expansion of capacities is planned due to lack of a large increase in demand for Russian energy resources and a significant interest in bioenergy [6], in the East the situation is different - potentially high demand stimulates development of new transport projects to supply basic energy resources - oil, gas and coal $[7,8]$.

Today, Russia has to switch to new markets and new consumers in order to maintain and/or increase its share and profitability in large-scale oil and gas projects.

In recent years, Russia has shown a slowdown in economic development: despite the high oil prices (which remained in the world market for several years), the growth rate of Russian GDP has been declining in recent years. Nevertheless, the share of fuel and energy in the country's economy, despite a significant decline in 2016, still remains significant $(22.6 \%)$ [9]. The share of fuel and energy in Russian exports has been decreasing since 2014 (from $70 \%$ in 2014 to $56.9 \%$ in 2016) [10]. Positive dynamics emerged in 2017 (Figure 2).
Russian oil is more difficult to extract, so under the sanctions and the falling prices the projects that give a new impetus to technological development can be stopped. First of all, these include projects for development of difficult and Arctic hydrocarbons [11].

The sanctions have already hampered equipment replacement in Russian oil and gas sector; its innovative development is slowing down, which can affect not only oil recovery coefficient and the shelf development, but also high-value-added products manufacturing - various types of synthetic fuels, petrochemical products, introduction of energy-efficient technologies $[11,12]$

\section{Prospects for diversification of Russian energy supplies to the Asia- Pacific countries}

The current conditions in the global market force Russia to diversify its energy policy, including development of Eastern and Southern export directions, which in recent years have shown high growth rates of energy consumption. First of all, these are the countries of the

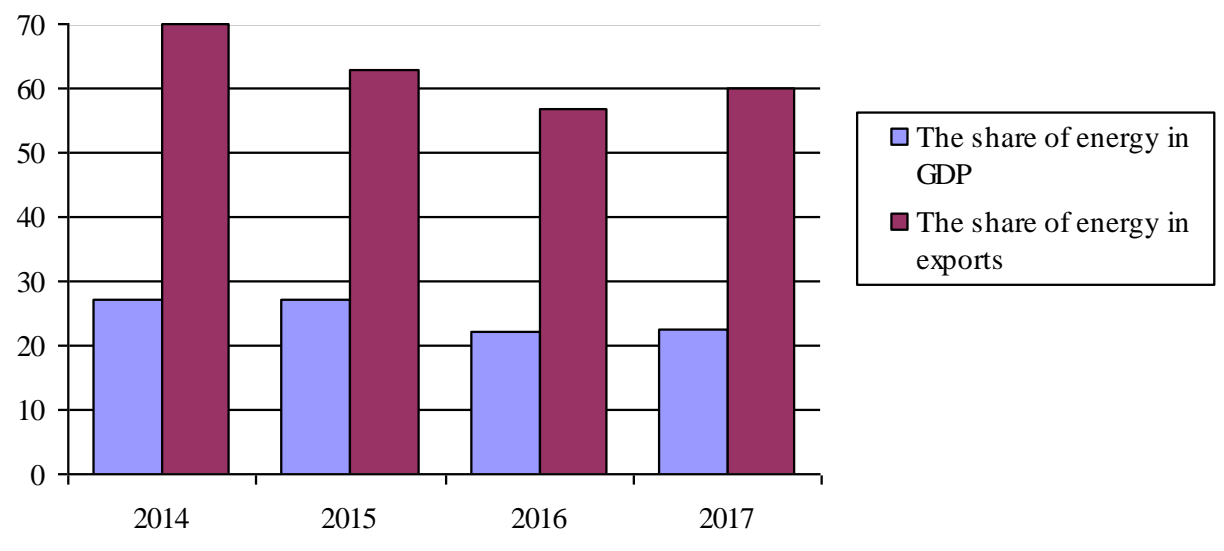

Fig. 2. The role of fuel and energy in the Russian economy. 
Asia-Pacific region (APR), close cooperation with which is a prerequisite for ensuring Russia's energy security in the current realties [13]. This is due to the fact that the newly industrialized countries demonstrate a consistently high economic growth and, accordingly, a consistently high increase in demand for commodities. Thus, the world consumption of primary energy resources, which has increased by $50 \%$ over the past 15 years, is almost completely provided by the demand of the Middle East and Asia. According to forecast estimates of the world experts, this trend of advanced energy consumption in the Asia-Pacific region will continue in the medium term, despite the slowdown in the growth rate of China's economy [9].

The general forecasts of oil demand in Asia-Pacific are quite optimistic. According to the Institute of Energy Economics, Japan (IEE), AP is expected to increase consumption of oil and petroleum products from 1,200 mln tons per year to $2,235 \mathrm{mln}$ tons by 2020 , and by 2030 to $2,800 \mathrm{mln}$ tons $[12,14,15]$. According to the International Energy Agency (IEA), by 2020, a growth is expected to $1,810-2,235 \mathrm{mln}$ tons per year, and by 2030 to $1,985-2,800 \mathrm{mln}$ tons per year. At the same time, the volume of oil imports will increase by 2020 from 1,050 mln tons to 1,446 - $1,816 \mathrm{mln}$ tons, by 2030 to 1,655 2,535 mln tons [12].

Additional opportunities for energy supplies to Asia will ensure an increase in exports. According to experts, the share of Russian energy exports to the Asia-Pacific countries is expected to grow from $15 \%$ in 2015 to $30-32$ or even above $40 \%$ by $2040[7,12,14]$. Thus, according to the forecasts of the Ministry of energy of Russia, by 2035 Russian exports of oil and petroleum products in this direction will increase 1.8-2.2 times, natural gas 8-9 times [14].

Building mutually beneficial energy relations between Russia and the Southeast Asian countries is a vital necessity for both parts. For Russia, this is important not only because of the opportunity of reducing risks, but for many other reasons as well. Refocusing of infrastructure projects and development of Siberia, the Urals, and the Far East is important in terms of the stability of the political and social situation and the territorial integrity of the country, as well as improving the attractiveness and quality of life in these regions. The Asia-Pacific countries can be not only consumers of energy resources, but also potential investors in joint raw materials extraction and transportation system development projects.

For the first time, the "Eastern Vector" of the country's energy policy was set in the "Energy strategy of Russia for the period up to 2020" and developed in subsequent policy documents: "Energy strategy of Russia for the period up to 2035". Today, cooperation with China, Japan, South Korea, and other Eastern partners in the oil and gas industry is mainly limited to joint projects (for example, PAO Udmurtneft), participation of Eastern investors in financing of national projects (Sakhalin-1), technological exchange (the activity of Japan Drilling Company in Vietnam) and directly export-import operations [16].
To date, Russian national supermajors (Rosneft, Gazprom) and Eastern counterparties have signed oil and gas supply contracts. According to the terms of these contracts, within 25 years China will receive more than $325 \mathrm{mln}$ tons of oil, as well as almost 1 trillion $\mathrm{m} 3$ of gas through the Power of Siberia pipeline (which is now under construction); Japan, China and South Korea Sakhalin Blend oil (more than $5.22 \mathrm{mln}$ tons) and LNG (more than $10.8 \mathrm{mln}$ tons) from Sakhalin-2 joint project $[16,17]$.

Among the most significant promising projects can also be noted the Hightech oil refining and petrochemical complex of PetroChina-Rosneft Orient Petrochemical Company Ltd. (Tianjin) and the Altai gas pipeline [17].

Experts and analysts agree that implementation of the above projects and the increasing cooperation between Russia and AP countries can make the following positive effects:

1) development of the Trans-Urals as an economic region of Russia, including infrastructure upgrade and employment generation in the Far Eastern Federal district;

2) the growing need for localization will potentially lead to development of national metallurgy, pipe rolling, and mechanical engineering, which in turn will have a beneficial effect on the rest of the country;

3) both parties will gain experience in investing in Russian projects, which will increase the confidence in them of Eastern investors and will significantly reduce dependence on Western sources of funding $[16,18]$.

However, there are certain risks associated with implementation of these projects. Thus, Chinese partners, despite the official position to expand purchasing Russian energy resources, are in fact delaying their obligations to finance capital construction (in particular, at the facilities of the linear infrastructure of the Altai gas pipeline). This obligation in such case falls entirely on Russia, which automatically increases the payback period of the project for another 5-10 years $[16,18]$.

Even economically feasible projects (for example, the pipeline to Japan) are postponed indefinitely for reasons unknown to the Russian party. And it is essential to recall that the competition for gas (both pipeline and LNG) and oil supply in the southern direction is extremely high: such countries as Azerbaijan, Algeria, Venezuela, Iraq, Iran, Qatar, Nigeria, Turkmenistan have the opportunity to actively influence the market.

Therefore, the focus on the AP countries as the main buyer of Russian energy resources is risky. Moreover, many countries among the potential Eastern partners are not planning to sell new technologies to Russia. Thus, South Korea supports tightening of environmental standards in the shipbuilding industry in order to eliminate competition on the part of Russia and prevent ice-class vessels supply for development of the national Arctic shelf [16].

In order to minimize the above risks and threats, the southern partners can be considered not only as consumers of Russian energy resources, but also as transit countries. Russia's energy cooperation with 
Turkey is a good example. Thus, at the end of 2016, Russian gas export to Turkey amounted to about $30 \mathrm{bln}$ $\mathrm{m} 3$. The gas was supplied partly through the Blue stream pipeline and partly through the Ukraine-RomaniaBulgaria gas pipeline (operation of which will stop in 2019). However, it is not so much the country's own consumption that is of interest, as the possibility of Gazprom to gain access to the Trans Adriatic Pipeline, thereby providing access to the Italian market $[16,18]$.

\section{Conclusions}

Russia, with its huge energy (including hydrocarbon) potential, plays an important role in ensuring global energy security. Russian economy is currently functioning and developing in a rather difficult external environment. In light of recent global political and economic events, the need for accelerated diversification of Russian energy exports is particularly acute.

One of the promising areas of hydrocarbon exports diversification is cooperation with the Asia-Pacific (AP) countries which in recent years have shown high rates of growth in energy consumption. Building mutually beneficial energy relations between Russia and the AsiaPacific countries, joint investment experience and implementation of mutual cooperation projects are an actual necessity for both parts. Therefore, despite a number of unresolved problems and the associated risks, the decision to diversify hydrocarbon exports as much as possible, focusing simultaneously on the three largest markets - China, Japan and South Korea - is the most reasonable, including from the point of view of ensuring Russia's energy security.

\section{References}

[1] E.V. Demidova Market Transformation of Energy Resources: Global Trends and Russian Realities Kazan Science 10, 25-8 (2016)

[2] E.V. Demidova The Place and the Role of Energy Security in the Modern World: Theoretical Aspects Journal of Economy and Entrepreneurship 11, 1197-1203 (2017)

[3] A.H. Shayakhmetova, F.V. Nazipova, R.R. Safin, A.L. Timerbaeva, A.V. Safina, Alternative types of solid biofuels and their comparative characteristics Int. Multidisciplinary Sci. GeoConf. Surveying Geology and Mining Ecology Management (SGEM 15th.) 53-8 (2015)

[4] R.R. Safin, A.S. Shaikhutdinova, R.R. Khasanshin, L.V. Akhunova, A.V. Safina, Improving the energy efficiency of solid wood fuel Int. Multidisciplinary Sci. GeoConf. Surveying Geology and Mining Ecology Management (SGEM 15th.) 315-22 (2015)

[5] E.D. Belotskaya et al Forecast of Development of Global and Russian Energy 2016 ed A.A. Makarov, L.M. Grigoriev and T.A. Microva (Moscow: ERI RAS-ATS under the Government of the Russian Federation) 196 (2016)
[6] R.R. Safin, R.R. Khasanshin, A.L. Timerbaeva, A.V. Safina, Study of the physical and energy properties of fuel granules based on a thermomodified wood raw material Journal of Engineering Physics and Thermophysics 4, 958-61 (2015)

[7] L. Grigoriev, et al Export Infrastructure of FEC: Transit Bypass in the West and Expansion in the East Energy Bulletin 47, 20-23 (2017)

[8] E.V. Demidova, V.V. Avilova, Fuel and Energy Complex as a Factor of Economic Safety of the State Economic Development in the 21st Century: Trends, Challenges and Prospects (Collection of Scientific Works of the 6th Int Scientific-Practical Conf. of Students, Postgraduates and Young Scientists "Horizons of Russia") ed V V Avilova and R S Dzarasov (Kazan: Kazan National Research Technological University Press) 350-3 (2018)

[9] E.V. Demidova, V.V Avilova, Energy Security: Challenges, Risks and Prospects (Kazan: Kazan National Research Technological University Press) 103 (2018)

[10] A.V. Novak, On the Main Issues of Development of the Fuel and Energy Complex at the Present Stage Presentation of the Ministry of Energy of the Russian Federation for the Report of $A V$ Novak to the Federation Council (Electronic Materials) ed Ministry of Energy of the Russian Federation (Moscow: Minenergo of Russia) 39 (2017)

[11] E.A. Telegina, New Dimension of Global Energy Security World economy and international relations 11, 5-16 (2015)

[12] A.V. Novak, et al Forecast of Scientific and Technological Development of the Fuel and Energy Complex of Russia for the Period up to 2035 (Moscow: Minenergo of Russia) 111 (2016)

[13] E.V. Demidova, V.V. Avilova, New Trends in World Energy Security: Global Players and Priority Changes Actual Issues of Economic Security (Collection of Scientific works of the 1st Russian Scientific-Practical Conf. of Students, Postgraduates and Young Scientists) ed V.V. Avilova and K.A. Grandonyan (Kazan: Kazan National Research Technological University Press) 72-9 (2018)

[14] The Draft Energy Strategy of the Russian Federation for the Period up to 2035 (Revised from 1st Feb 2017) (Moscow: Minenergo of Russia) 78

[15] International Energy Outlook (IEO2016) (Washington: U.S. Energy Information Administration) 276 (2016)

[16] O.B. Lomakina, Strategic Interests of Russia in the Field of International Energy Security M.I.R. Modernization. Innovation. Research 4, 25-34 (2016)

[17] V.V. Avilova, and E.N. Porfiryeva, Strategic Competitiveness of Russian Oil and Gas Companies Bulletin of Kazan Technological University 20, 280-3 (2014)

[18] M.O. Ryazanova, Energy Cooperation within the BRICS: Relevance of the Issue Bulletin of MGIMO 4(94), 7-11 (2015) 